\title{
Traders as Diplomats: Trade and Sino-American Rapprochement, 1971-78
}

\author{
Mao $\operatorname{Lin}^{1}$ \\ ${ }^{1}$ Department of History, P.O. Box 8054, Georgia Southern University, Statesboro, GA30460, USA \\ Correspondence: Mao Lin, Department of History, P.O. Box 8054, Georgia Southern University, Statesboro, GA30460, \\ USA.
}

Received: August 14, 2017

Accepted: August 29, $2017 \quad$ Available online: September 26, 2017

doi:10.11114/ijsss.v5i10.2670

URL: https://doi.org/10.11114/ijsss.v5i10.2670

\begin{abstract}
During the 1970s, U.S.-China relations went through a major strategic transformation. To oppose their common enemy, the Soviet Union, the two countries ended hostilities which lasted for more than two decades and became Cold War allies. Many scholars have discussed this major historic turning point, however, most scholars have focused exclusively on the strategic relations between the two countries, while ignoring bilateral economic and trade relations. This paper argues that trade relations actually constituted an important aspect of American foreign policy towards China. And the development of trade relations in the 1970s was mainly promoted by American businessmen. These American businessmen not only hoped to open the Chinese market, but also consciously regarded themselves as "unofficial ambassadors", because they believed that trade will contribute to the improvement of the relations between the two countries. By developing trade with China, the United States expected to transform China into a market-oriented economy, and eventually change the political nature of the Chinese regime.
\end{abstract}

Keywords: U.S.-China Relations, U.S.-China Trade, Cold War, modernization

\section{Introduction}

A major turning point of the Cold War happened in the 1970s when the People's Republic of China and the United States established normal relations and became strategic allies against the Soviet Union. This Sino-American rapprochement not only produced high political dramas such as Henry Kissinger's secret visit to China and Richard Nixon's historic meeting with Mao Zedong, but also profoundly shaped the rise and fall of Cold War détente and the so-called Sino-Soviet-American triangular diplomacy. Naturally, Cold War scholars focus on issues of "high politics" such as the Sino-Soviet split, the war in Vietnam, the status of Tai wan, and other strategic issues to understand why and how the U.S.-China rapprochement happened (Segal, 1982; Garver, 1982; Sutter, 1983; Chang, 1990; Harding, 1992; Garthoff, 1994; Foot, 1995; Chen, 2001; Xia, 2006; MacMillan, 2007; Komine, 2008; and Tudda, 2012).

While strategic concerns contributed to Sino-American rapprochement, we can no longer afford to push aside issues such as trade and economic exchanges between China and America as "low politics," since one consistently repeated thesis that underlined this new Sino-American relationship was the need for America to "bring China back into the international community," which suggested America should influence China's modernization by engaging the Beijing regime both economically and culturally (Nixon, 1967). Throughout the 1950s and 60s, China maintained a radical and revolutionary foreign policy that was unpredictable and largely hostile to the West. Thus for American leaders, China's behavior could only be moderated if its stakes in the current international order, as preferred by the "Free World," could be raised high enough. To achieve this goal, America not only had to make major strategic changes, but also needed to expand economic relations with China. In a sense, the most important significance of Sino-American rapprochement was that China gradually rejoined the global political and economic system and its own modernization became intertwined with trends in the West.

During the 1970s, trade played a crucial role in America's effort to bring China back into the international community. A quick survey of the literature, however, reveals that the study of U.S.-China trade in the 1970s, although not completely overlooked, is underexplored by scholars. For example, Harry Harding's pioneer work, A Fragile Relationship, argues that trade and other unofficial relations were merely used by Beijing and Washington to sweeten the two nations' strategic dialogues (Harding, 1992). Warren I. Cohen's classic work, America's Response to China, barely mentions trade in his discussion of U.S.-China rapprochement (Cohen, 2000), a tendency shared by other popular surveys of U.S.-China relations (Fairbank, 1983; Schaller, 2002; Sutter, 2010; Wang, 2013; Xu, 2014). Rosemary Foot's 
well-accepted work, The Practice of Power, regards bilateral trade as an issue dependent on strategic relations, arguing that "the economic relationship between the United States and China in the 1970s lacked a stable basis" and "high expectations regarding the China market remained unfulfilled." (Foot, 1995, pp. 75-77) Indeed, the tendency to downplay the significance of trade in Sino-American rapprochement is widely shared among scholars (Ross, 1995; Tyler, 1999; Mann, 1999; Garrison, 2005; Ali, 2005; Kirby, Ross, \& Gong , 2005). ${ }^{1}$ This gap in the scholarship is especially curious because the discussion of trade looms large in the literature of Cold War U.S.-China relations. However, the literature overwhelmingly focuses on either the American trade embargo against China or the trade boom after the establishment of official diplomatic relations in 1979 (Tucker, 1983; Mastanduno, 1992; Foot, 1995; Ross, 1998; Zhang, 2001; Jackson, 2001; Kochavi, 2002; Peck, 2006; Qing, 2007; Lumbers, 2008; Førland, 2009; Chang, 2015).

While the mainstream literature at least regards Beijing and Washington's official trade policies as of secondary importance in Sino-American rapprochement, it almost allows no room for private American businessmen and businesswomen in its narrative. This overlook cannot do justice to the rich history of Sino-American business encounters in the 1970s. In fact, for most Americans in the 1970s, trade with China became one of the most important results of Sino-American rapprochement. On the one hand, the perceived China market of 800 million consumers suddenly came to dominate the imagination of the American business community. For many American business executives, this potential China market became a vital outlet for them to get out of the economic recessions of the 1970s. On the other hand, Sino-American trade became the most visible symbol of U.S.-China detente. Chinese goods displayed in New York City department stores said a lot about the improved relations between the two nations, which, in return, reinforced the lure of trade with China. The mainstream literature, however, has yet to integrate those business encounters into its narrative, instead of treating them as mere historical antidotes and dinner talk materials.

It is high time, therefore, to take a fresh look at the development of U.S.-China trade in the 1970s. This article examines the development of U.S.-China trade between 1971 and 1978, primarily with a focus on the stories of individual businesspersons. First, it examines how the American business community approached and perceived the Chinese market and the major problems and issues of the bilateral trade. Second, it argues that America's interest in the China trade was never purely economic; rather, American business people regarded themselves as both traders and unofficial diplomats who could both get rich in China and help to improve Sino-American relations. Finally, those unofficial diplomats" perception of the China trade was based on their perception of China's failed modernization under Communism. To many American traders, China clearly failed to become a first rate industrial power through the communist model of modernization. As a result, China would have to seek new economic relations with the West to acquire technologies and managerial skills for its own modernization. Many American traders were thus enthusiastic about US-China trade because they believed that reopened economic relations with America would persuade the Chinese to abandon their communist model of modernization and move closer to the capitalist model. They were confident that this strategy could work because they perceived the Chinese modernization under communism as a failure and thus believed that China would have no other choice but to embrace the American model. If America could influence China's future development through the attraction of its capitalist model, then the U.S.-China strategic alliance would be further consolidated by the shared economic interests and developmental visions. ${ }^{2}$

\section{Initial U.S.-China Business Encounters: 1971-1972}

"After a 20-year embargo, American corporations have begun to do business with Communist China." So announced the Wall Street Journal in a front-page article: "The flow of American products and technology into the People's Republic has just started....And many businessmen who have no trade with mainland China now are seeking it." Already, an optimistic atmosphere existed. "You just can't look at a market of that size and not believe that eventually a lot of goods are going to be sold there," a spokesman of a drug company mused. "One aspirin tablet a day to each of those guys, and that's a lot of aspirin." The newly developed China trade would "help American businessmen compete more effectively for sales abroad even when the China-bound portion is insignificant." (Kwitny, 1971)

This kind of enthusiasm for U.S.-China trade might sound naive, as it e voked the stereotyped image of China as a huge and natural market for America. But many American businessmen and businesswomen were anything but naive regarding the potential for trade with China. While the lure of China market was the talk on the street, many people

\footnotetext{
${ }^{1}$ The only exception that proves the rule is Cheung, 1998. Cheung argues that Nixon's visit of China was the result of "market force" and America's desire to improve relations was driven by domestic economic pressures. However, Cheung's thesis has, by and large, been ignored by scholars.

${ }^{2}$ This article is developed in light the recent historiographic trend to review the Cold War as a competition between the America (West) model and the Soviet (Communist) model of modernization.
} 
cautioned about the uncertain prospect of U.S.-China trade and the limited potential of the Chinese market in the immediate future. For example, the American Management Association told its members that "patience and long-term planning, rather than expectation of quick sales and profits, are characteristic of the advice most often given American businessmen by China trade experts and other consultants."(AMA, 1972, p. 4.)

So why did American traders believe that it was worth the effort to invest time and money in this China market? A key reason was that many shared the assumption that China's modernization had failed under communism. As a result, many business executives were convinced that the development of substantial trade between America and China was inevitable, since China needed American technologies for its own modernization. Moreover, many American traders not only wanted to do business with China, but also considered themselves as unofficial diplomats who could contribute to the development of Sino-American rapprochement and increase America's influence over China's modernization strategy. Thus, the combination of economic gains and a certain kind of emotionalism convinced many Americans that it was worth the effort to develop trade relations with China.

The potential economic benefit of trading with China was something that many in the American business community could not ignore; no matter how limited the China market was at that time. The China market turned out to be promising for some American industries as soon as the American economic embargo on China was lifted. In fact, the American media quickly started to report sensational stories of successful trade deals between America and China. One case was a possible deal between the Boeing Company and China, which the public followed closely. The deal was initiated by the Chinese because they were impressed by Boeing aircraft during Nixon's visit. Yet for ordinary Americans, this deal far surpassed their expectations of the resumed trade with China. The technologies involved in such a deal seemed too advanced and strategically important to be exported to China. "Incongruous thought for the day," the Wall Street Journal reported. "A leading U.S. defense contractor providing the official plane for Chairman Mao and Chou En-lai." (WSJ, 1972a) The deal, however, was quickly cleared by the Commerce Department, and in September 1972 Boeing announced that China had decided to purchase ten 707 aircrafts and pay the price of about $\$ 150$ million in cash. (WSJ 1972b, 1972c) The Boeing story, together with other success stories, certainly encouraged the American business community.

For many shrewd American business executives, a sole focus on the cash value of the Boeing deal was rather superficial. For them, the key point behind that deal was the Chinese need for advanced technologies, which was perceived as a natural outcome derived from China's goal of modernization. Moreover, many American business people were convinced that modernization was a long-term project for China, thus guaranteeing a lasting need for American products and technologies. As a result, they saw the two countries" economies as structurally complementary, with China providing raw materials and cheap labor in exchange for foreign currency and manufactured industrial goods. In other words, China badly needed to trade with America, and this need ensured the development of the China market.

Accordingly, many American business executives approached the China market with long-term planning. For example, one American business executive argued that the complementary economic structures between America and China were crucial for his company's survival. "The pottery and glassware industries are dying in the United States and the West in general," he told some newcomers to the China trade. "This is a very hot and dirty industry to work in and the American workers are turning away from it altogether. I think the future of this industry lies in China where they have manpower. This is why my company has been looking toward China for long term goals." ${ }^{3}$ Murray Berger, chief executive of an American seafood company, recalled that he became interested in the China market during the late 1960s, when he looked at China's coastline and realized that China was going to be the "largest seafood producer." He kept writing letters to China every six month for possible trade deals, and finally he was invited to attend the Canton Fair in the spring of 1972. He recommended being "a regular buyer through good and bad times, high markets, low markets....One day [you] will be rewarded."4 Bob Boulogne, director of international buying of JC Penny, once summarized the need to be patient: 'We don't dare to go out of this market...because we know it's got to develop....In other markets we would say, well, we'll come back when it is ready. With this market...we cannot take that chance....We are hanging on and we are learning.",

American traders' optimism about the future of China market was reinforced by their conviction that China genuinely wanted to do business with the United States. Such a conviction was established through some high-profile business deals made between the Chinese government and American companies. For example, RCA Global Communications

\footnotetext{
3“Pre-Canton Fair Briefing," 5 April 1977, National Council for U.S.-China Trade (NCUSCT), Box 71, Gerald Ford Presidential Library (GFPL). Ann Arbor, MI.

4‘Interview with Murray Berger,”NCUSCT, Box 373, GFPL.

5"Interview with Bob Boulogne," NCUSCT, Ibid.
} 
was the company that set up the satellite ground station in China for Nixon's visit, and the Chinese were obviously impressed by America's modern communication technologies. As a result, China signed a $\$ 2.9$ million contract with RCA in early 1972 and another contract worth $\$ 5.7$ million later that year. RCA was hired to build satellite ground stations in China, which would provide China with the most advanced international communications facilities for expanding the country's direct television, telephone, telex, and date communications links around the world. The RCA found the Chinese keen students of American technologies. The Chinese "were efficient and orderly in our business dealings," RCA's chairman Howard Hawkins recalled. "They seemed pleased with our interest in their country and exhibited a genuine interest in the American people." Hawkins also realized that the Chinese government planned trade strategically, with priorities put on technologies and products crucial to China's modernization. This scheme convinced Hawkins that "the Chinese are sincerely interested in de veloping trade with the United States." Thus he suggested other American companies to "establish your business purpose, credibility, and the need for your products or services." Meanwhile, "never expect to fly in, make a fast deal, and leave quickly." (Boarman, 1974, pp. 133-138.)

The belief that China's modernization would be a stable driving force behind U.S.-China trade was also shared by the Boeing Company. When a Boeing sales team visited China in April 1972, the Americans discovered that the Chinese eagerness to appear proud of China's economic development under communism only belied their desire to get advanced technologies from America. The Boeing people traveled within China on Soviet-made airplanes, and as experts in the aviation industry they were aware of the obsolete Chinese aircrafts. "They can do much better if they so desire," the Boeing team concluded, obviously sensing a potential deal between China and Boeing. When they sat down for business, the Boeing team found that the Chinese "appeared to have a very strong interest in knowledge of the Boeing Company, what our product line is, and of course details of our aircraft." The Chinese also indicated that China did not regard a contract with Boeing as a one-time deal. Rather, China wanted to use the relationship to completely modernize its aviation industry. ${ }^{6}$

For many American promoters of U.S.-China trade, the RCA and Boeing cases were not isolated success stories. Rather, the two cases revealed that China's modernization could lead to stable trade relations. This revelation prompted the state government of Washington to establish a China Trade Development Council as early as 1971. As the home state of the Boeing Company, Washington believed that the whole northwest region of America could develop close trade relations with China. $^{7}$ On July 8, 1971, a few days before Kissinger's first secret visit of China, the State sent a letter to the Chinese embassy in Canada inquiring about trade possibilities. The letter pointed out that the State of Washington traditionally took a leadership position in promoting trade with China, and now it had at least two kinds of products that could satisfy China's needs - agriculture products such as wheat and advanced technologies. ${ }^{8}$ In July 1971, the state sent a delegation to Hong Kong, trying to establish contacts with China. While the delegation did not get a clear response, given the sensitive timing of the contact, it was certainly not discouraged. The delegation discovered that China relied heavily on the Hong Kong middlemen to export its goods indirectly into America. Such a discovery suggested the potential gains once direct U.S.-China trade was established. Moreover, when the Beijing government sent an agent down to Hong Kong to meet the delegation, it was revealed that China kept a good record of all the past letters sent from the state to China asking for trade.

Nixon's visit of China further wetted the State's appetite in doing business with China. In March 1972, for example, the State prepared a detailed plan for developing trade with China. The plan argued that China's desire for modernization constituted a reliable foundation for expanding trade between the State and China. "The major problem of industrialization stands before the Chinese," the plan concluded: "The Chinese would like to acquire the know-how necessary to build cars, refrigerators, and washing machines. And they can be expected to turn more and more to Western nations for assistance, since trade with Russia seems out of the question... [Therefore, China would find] a ready market in the US." 10

\footnotetext{
6“"Trip to China," April 1972, Record Group Commerce \& Economic Development, Trade Development, Box 55, Washington State Archives (WSA), Olympia, WA.

${ }^{7}$ The state government gained support in its effort from the Seattle Chamber of Commerce. On June 8, 1971, the Chamber adopted a resolution, arguing that in light of the recent Nixon initiative the city should grasp the opportunity to position itself as a future leading trade partner of China. "The volume [of U.S.-China trade] is steadily increasing and one can anticipate that in due course, a country with a population estimated at 750-850 million people will not only become an excellent market but also a good source of supply," the resolution concluded. See "Resolution," 8 June 1971, Ibid.
}

${ }^{8}$ Letter, 8 July 1971, Ibid.

${ }^{9}$ Memo, "Contacts in Hong Kong with PRC Representatives," 13 September 1971, Ibid.

10“Trade with Red China,” March 1972, Record Group, Governor Daniel Evans, Commerce, Box 2S-2-635, WSA. 
At the same time, trade promoters also argued that American businessmen and businesswomen could function as unofficial diplomats to China. This stance was keenly encouraged by the Nixon administration, which regarded trade as an important tool to achieve the U.S.-Chinese rapprochement. In 1972, the Nixon administration established a new Bureau of East-West Trade within the Department of Commerce. The Bureau immediately started to promote trade with China among American businesses. "Trade between our two countries has more than just economic significance. Or even if the volume of trade remained statistically microscopic — which is not likely — there are advantages to be derived from focusing attention on it," the Bureau argued. "Trade negotiations by private American firms may prove to be an especially significant arena for building mutual trust and confidence." 11

The Nixon administration's emphasis on the political implications of U.S.-China trade was widely shared by American business people. In fact, American traders understood that they could not approach China from a pure business angle. Otherwise, as Victor Li wrote, "the Chinese would see the "typical" ugly American capitalist who thinks money creates access to all things and who lacks any sensitivity to Chinese preferences for methods of doing business." The correct approach, Li argued, was to show sympathy for and understanding of China's modernization first, and to indicate genuine willingness to become China's friends. "[If] many of the American 'ambassadors'...perform well, they not only will economically benefit themselves but also will help pave the way for improved political relations between the countries." (Stahnke, 1972, pp. 209-211.) This correct approach would not only avoid creating misunderstandings between the two sides, but also would give America the long-term leverage of influencing China's future development. "The Chinese now are where the Russians were in 1925," Samuel Pisar, another China trade promoter, argued: "The first flush of revolution is over. They have the problem of industrialization. They cannot do it by themselves. They tried in a romantic and unscientific way and it didn't work....By bringing [the Chinese] back into the world market, by helping them with the know-how to build cars, refrigerators, washing machines, we make their society more complex. The force of their prosperity pushes them in the right direction." (WSJ, 1971)

In sum, through the initial business contact with the Chinese, American traders perceived a long-term market in China. The Chinese desire to trade with America in order to benefit their own modernization convinced many Americans that they should invest money and time in this future market even if there were no quick gains. Moreover, many American traders believed that they should and could play the role of unofficial diplomats, who would help China to change its failed modernization strategies. However, once trade took off after Nixon's 1972 visit to China, American traders quickly discovered that China's modernization strategies could both help and hurt bilateral trade.

\section{U.S.-China Trade and Its Problems: 1972-1974}

The period between 1972 and 1974 can be regarded as the first stage of direct U.S.-China trade. While trade was resumed in 1971, it was in 1972 that the bilateral trade really became a two-way activity and American business people started to visit China in large numbers. From 1972 onward, U.S.-China trade developed quickly in terms of the rate of growth, although the absolute value of bilateral trade was small. Meanwhile, American traders and their Chinese counterparts formed new perceptions of each other and adjusted their trade strategies accordingly. The first stage of direct trade, therefore, both tested the strength of the new Sino-American economic bond and paved the way for future trade relations.

Table 1. U.S.-China Trade, 1971-79 (\$ Million)

\begin{tabular}{cccc}
\hline Year & US Exports & US Imports & Total \\
\hline 1971 & 0 & 4.9 & 4.9 \\
1972 & 63.5 & 32.4 & 95.9 \\
1973 & 740.2 & 64.9 & 805.1 \\
1974 & 819.1 & 114.7 & 933.8 \\
1975 & 303.6 & 158.3 & 461.9 \\
1976 & 135.4 & 201.9 & 337.3 \\
1977 & 171.3 & 202.7 & 370.4 \\
1978 & 818.2 & 324.1 & $1,147.7$ \\
1979 & $1,716.5$ & 592.3 & $2,308.8$ \\
\hline
\end{tabular}

Source: US China Business Review, various issues 1972-1979.

For the American business community, the good news of 1972 was that China finally decided to invite American business people to visit the Canton Fair. The Canton Fair, held twice annually, accounted for 30 to 50 percent of China's total foreign trade. In addition, for foreign traders, the Fair was practically the only opportunity to meet face-to-face with the Chinese to conduct business negotiations. Not surprisingly, Americans who were invited to the Fair felt excited and flattered, as they understood that the Chinese regarded them both as useful to China's modernization and as unofficial

\footnotetext{
11“US Trade Prospect with the PRC,” December 1972, NCUSCT, Box 4, GFPL.
} 
diplomats who could help to strengthen bilateral relations. "It is clear that the Chinese are going to invite only those whom they think are important to China," an American business executive who went to the 1972 Spring Fair reported. "I think most of the Americans who were invited to the Canton Fair...had been working toward an improvement in the relationships between our two countries." The proud business executive then announced that "they gave us VIP treatment." (Boarman, 1974, pp.114-115.) Julian Sobin, chief executive of Sobin Chemicals, thought a new age of U.S.-China relations had started. "We Americans got the message," he declared: "the magic and profit-making had been hidden from us long enough; this was the world of China Trade, swirling with rumor and reality." 12

The excitement among American traders was not surprising. For most of them, the trip to the Canton Fair itself was more important than the actual business deals negotiated, at least initially. Most of them found it essential to establish "friendly" relations with the Chinese before the actual conduct of business. In order to do so, for example, a representative for Alexander's told the Chinese that her store was "the people's store" and now "we will start to walk together, but like children we will trip many times." Another group of buyers from New York were so excited about their experiences in China that "they sound more like children suddenly let loose in Santa's workshop" than mature executives. (Brozan, 1972, p.42.) Indeed, the excitement softened the tough negotiating tactics of American traders. "Maybe because I'm so grateful that I'm there," David Cookson of ICD Group recalled: "no matter how many times I've been there for some reason I get into a mood...that they've accorded me some great honor by allowing me to negotiate with them, to go to their country and so forth and then everything falls into place and I yield too quickly and I don't negotiate quite as hard as I do in other places and I forgive more easily when they're late in shipments or materials which doesn't quite come up in standard." 13

Americans were also amused, if not frustrated, that they were unable to take the initiative in trade, because the Chinese only allowed Americans to participate the Canton Fair as invitees. Americans had no way to know the Chinese criteria of selection, and some of them were even surprised that they were chosen. Julian Sobin, for example, wondered why he was invited to the 1972 Spring Canton Fair on his way to China. The only reason he thought credible was that his company, a large chemical producer, might be regarded as "useful" to China's economy. Sobin thus decided to try his best by following the trade promoters' advice. Unable to sell his products to the Chinese during the Spring Fair, Sobin nevertheless purchased $\$ 400,000$ worth of Chinese chemical products. After he returned, his office kept almost daily communications with the Chinese. Finally, Sobin was rewarded in the 1972 Fall Canton Fair, when he sold $\$ 600,000$ worth of unspecified inorganic chemicals to the Chinese. The total trade with China in 1972 would reach $\$ 4$ million, representing 9 percent of the company's entire business. ${ }^{14}$

Although American traders were kept in the dark since the Chinese were unwilling to provide information that would illuminate China's trade operations, they believed that China was carefully coordinating its foreign trade according to its modernization blueprint. When the Chinese found something that could contribute to China's modernization, they would move quickly and negotiate hard to seal a deal. For American traders, this pattern proved that the foundation of the new bilateral trade was solid and sound. For example, Wallace Chavkin, another American invitee to the Canton Fair, concluded that "[U]nder its fourth Five-Year Plan, which ends in 1975, China plans to modernize its steel, machinery, automobile, and shipbuilding industries, in addition to developing its air, overland, and maritime transportation systems. All of these are areas in which the United States could be actively participating - trade areas that could mean substantial business for our country."(Whitson, 1974, p. 419.)

The American traders' feeling of being used as a pawn in the Chinese grand foreign trade strategy was justified by China's own planning. On March 22, 1972, the Chinese Foreign Trade Ministry issued an instruction entitled "On U.S. -China Trade," which set the basic framework for bilateral trade with America. This instruction made clear that trade with America was closely associated with the overall state of U.S.-China relations. "Trade with America must be conducted on the basis of equality and reciprocity," the instruction dic tated. "The progress of trade will be decided by America's attitude toward us." But the instruction also hinted that the ideological tone associated with foreign trade in the past should be watered down. Besides inviting American traders "who have been friendly to China," the Canton Fair should also invite "representatives of the monopoly groups who can provide advanced technologies to China." Chinese delegates could feel free to offer certain goods not on the trading list composed beforehand if asked by American traders. The instruction also urged Chinese traders to study the rules of international trade. "When dealing with Americans, we must study their market and business practices," the instruction read: "we must pay attention to the quality of our goods and observe the contacts strictly." More importantly, trade with America was going to be planned and controlled by central authorities. China

\footnotetext{
${ }^{12}$ Julian Sobin, "Pilgrimage to the Canton Fair," 1972, RG40, General Record of the Department of Commerce, Office of the Secretary, 1953-1974, Box 352, NAII.

${ }^{13}$ Interview with David Cookson, NCUSCT, Box 373, GFPL.

14“Canton Autumn Fair Marks Breakthrough in Sino-US Trade," 24 November 1972, RG40, Box 352, NAII.
} 
wanted to sell its products to America as much as possible, but it would "strictly control imports from America" and China would "import advanced technologies first." 15

Meanwhile, the Chinese were optimistic about the future of Sino-American trade. The reason can be found in the Chinese perception of the world market in general and the American market in particular. On April 5, for example, the Foreign Trade Ministry urged its local branches to take advantage of the current situation in world markets to develop China's foreign trade because 1972 was going to be a year of "economic crisis in the capitalist world." The Ministry predicted three trends in the world market. First, the economic growth rate of the capitalist world would slow down dramatically, with a high rate of inflation and unemployment. Second, there would be fierce competition among America, Western European countries, and Japan for foreign markets. Finally, the dollar-based currency system would become unstable. This situation would position China advantageously in international trade. "The Nixon visit paved the way for direct U.S.-China trade," the Ministry asserted. "Although we are not yet prepared to have a great leap in the bilateral trade, they (American traders) were crying for doing business with us." China, therefore, should grasp the opportunity to "buy low" in the world market for raw materials and machines that China did not produce. ${ }^{16}$

The Chinese perception of the American market thus convinced China's planners that China could control the initiative in the bilateral trade. Naturally, American traders were increasingly frustrated by the Chinese way of doing business. First, American traders quickly realized that they were not dealing with Chinese business people, but trade officials. Foreign trade in China was controlled by the Foreign Trade Ministry, which had eight major Foreign Trade Corporations (FTGs). Each FTG controlled a specific trade area, such as machinery, raw materials, agricultural products, and so forth. This Chinese trade structure was confusing to many Americans. For one thing, the Americans had trouble telling the ranks among the Chinese negotiators, since they all wore similar "Mao jackets" and they usually skipped over titles during introductions. As one American trader complained, "You don't know if the guy sitting across the table from you is top brass or a flunky." ${ }^{, 17}$ Americans were also frustrated by the Chinese evasiveness during trade negotiations. One trader complained that every time he raised a tough or direct question, the Chinese politely offered him a cup of tea without giving him any useful information. (WSJ, 1972d) Another trader participated in the following discussion when he wanted to buy from the Chinese: 'Do you have any Tibet plates? No. Do you have any kolinsky? No. Do you have any rabbits? No. Well, what do you have for sale? What do you want to buy?" (Boarman, 1974, p. 111.) American traders quickly discovered that the Chinese evasiveness was caused by the fact that on-site Chinese representatives lacked authority to make decisions that would deviate from pre-made instructions.

Second, Americans were quite annoyed that China's trade practices did not fit with the American way of doing business. As Jerome Cohen pointed out, "the most striking thing to the newcomer to the Chinese business environment and legal environment is there's no ready proof that China has a legal system in the conventional western sense." The Chinese preferred short-term contracts and they were suspicious about the role of arbitration and insurance in the bilateral trade. When there were disputes or violations of contracts, the Chinese preferred settling the problems by "friendly discussions." The Chinese were also reluctant to take credits or loans in foreign trade, because they believed that debt occurred in trade would render China dependent on "foreign masters." Thus they were particularly eager to maintain balance between exports and imports. Neither did the Chinese really understand the rules of the American market. For example, one major Chinese grievance was about the regulations of the US Food and Drug Administration (FDA). Although American traders tried to assure the Chinese that the rules of FDA were applied equally to all countries that were exporting to America, the Chinese insisted that FDA was "created" to discriminate against Chinese goods. China also failed to understand the importance of packaging in the American market. American buyers frequently discovered that damage to their goods such as glassware or craftworks was inevitable due to improper packaging. In short, the Chinese had a long way to go to become real businesslike in the eyes of American traders. ${ }^{18}$

Finally, Americans were also concerned that while China wanted advanced technologies from America, it would not buy American consumer goods. "Clearly, consumer goods aren't high on the list of goods China hopes to ac quire from the U.S.," the Wall Street Journal concluded. "The Chinese aren't much interested in such 'frills,' and they feel they produce enough consumer goods of their own." For Americans, however, it was crucial to make the Chinese interested in purchasing such consumers goods as washing machines, air-conditioners, and TV sets that Americans took for granted. In other words, whether or not China would buy those consumer goods was an important indicator of how far China would drift away from its old economic model. (WSJ, 1972d)

\footnotetext{
15“On U.S.-China Trade,” 22 March 1972, 324-2-117, GuangDong Archives (GDA), Guangzhou, China.

16“"The Prospect of Trade of the Capitalist World in 1972 and Its Influence on Our Trade," 5 April 1972, 324-2-118, GDA.

${ }^{17}$ Letter, November 1975, NCUSCT, Box 188, GFPL.

${ }^{18}$ Interview with Jerome Cohen, William Clarke, David Cookson, NCUSCT, Box 373, GFPL.
} 
The problems of the U.S.-China trade did not discourage American traders. Instead, leading American business people and concerned public officials started to organize traders to deal with those problems. Thus the National Council for U.S.-China Trade (NCUSCT) was founded in May 1973 as an "umbrella" organization dealing with trade issues with China. ${ }^{19}$ From the very beginning, the council leaders saw trade as a major tool to influence China's future modernization. William Casey from the State Department told his audience during the first Council meeting that trade with China would "bring into an economic equation which will require scaling down [China's] commitment to arms as it becomes necessary to expand the commitment to trade and development." He declared that "we believe that a world situation in which China is prospering and improving the life of its citizens is as important to us as it is to the rest of the world. Trade is one of the ways to further this objective." ${ }^{, 2}$ Lucian Pye, another speaker at the meeting, agreed. "Trade is one of, if not the, most effective bridges between our very different social systems." For Pye, Americans only faced one customer in China: the Chinese government. He argued that given China's "disciplined, skilled, and cheap labor" and the "great need for modern technology," that customer would eventually become more flexible regarding its communist economic model. No doubt, he envisioned American traders to play a leading role in bringing this about. ${ }^{21}$

Christopher Phillips, president of the National Council until 1986, later recalled that intense American interest in the China trade made the council an immediate star in the business community. Phillips understood that "fascination for China and things Chinese has had a particular impact on Americans" and he immediately devoted himself to the council's work. ${ }^{22}$ From the beginning, the National Council focused on "educating" the Chinese on doing business in the American way. In November 1973, the Council sent its first delegation to China. In Beijing, William Batten, chairman of JC Penney, reminded his host of 'the need for China to address itself to such matters as identification of market opportunities for specific Chinese exports, identification of product requirements in terms of quality, design and pricing, and application of certain federal and state laws and regulations with respect to product safety and consumer information." William Hewitt, chair of Deere and Company, told the Chinese that they would "need to have reciprocal exchanges of information." (CBR, 1974a) The Chinese might resent the Americans lecturing them on how to conduct trade, but at least they were willing to listen. Encouraged, the Americans decided to help the Chinese as much as possible. For example, one council member wrote that "I really think we should help the Chinese screen some of the Fair goers." She meant that the council should run credit checks and gather necessary information for the Chinese. In other words, the Council assumed a role of patronage toward the Chinese. ${ }^{23}$

During the first stage of U.S.-China trade, the National Council achieved limited success in "educating" the Chinese. On the one hand, the early problems in the China trade persisted. For example, the Chinese lack of understanding of the American market was still a major problem. "Often difficulties in the clothing trade stem from a lack of understanding of the other country's market," an American trader reported. "The gulf between the multifarious world of "Seventh Avenue" and the Chinese ethics of frugality, modesty and practicality is vast." (CBR, 1974c) The Chinese suspicion of for eign economic "exploitation" continued to be powerful. Chinese food producers still refused to use American labels on their products because "they wish to develop a US market for Chinese brands and not become anonymous suppliers to large wholesale houses or retail chains." The Chinese also set their prices too high and had the same price for wholesalers and retailers. "In market economies, this problem is ordinarily solved in the marketplace," an American trader lamented. "In China, foreign trade apparatus is presently too inflexible to accommodate these varied pricing demands." (CBR, 1974d)

On the other hand, American traders also perceived greater flexibility on the Chinese side and a slow shift of China traders to follow the American way of doing business. For example, Americans at the Fall 1973 Fair 'found the Chinese to be more accommodating and more willing to complete negotiations on an expedited basis than at any time previously. Prices were higher, but [there was] little complaining among Americans about prices." (CBR, 1974b) At the same time, "both the Light industries and Textiles corporations have increasingly shown willingness to modify the design of their products for American market conditions." (Lubman \& Lubman, 1974) The Chinese even invited an America fashion designer into China to help design apparels for the American market. "I posit that the Chinese should study what can be made and make adoptions, then work out a marketing method," the designer reported, and she thought her hosts took her advice well. (Tillett, 1974).

The mixed trend in Chinese trade behavior encouraged the Americans more than discouraged them. That China was

\footnotetext{
${ }^{19}$ Memo, Kissinger to Secretary of Commerce, 16 April 1973, RG40, Box 352, NAII.

${ }^{20}$ Speech by William Casey, 31 May 1973, NCUSCT, Box 4, GFPL.

${ }^{21}$ Speech by Lucian Pye, 31 May 1973, Ibid.

${ }^{22}$ Oral History of Christopher Phillips, Foreign Affairs Oral History Collection (FAOHC), Library of Congress.

${ }^{23}$ “First Annual Report,” June 1974, NCUSCR, Box 177, GFPL; Letter, 13 May 1975, NCUSCR, Box 188, GFPL.
} 
becoming more and more willing to adhere to the American way of doing business, no matter how slowly, was actually the best result American traders could achieve during the first stage of direct U.S.-China trade. At least the problems were identified and efforts were made to overcome the trade barriers inherent in the Chinese trade structure. Indeed, the National Council leaders started to see that they were helping to build a marketing mentality among their Chinese counterparts. However, whether or not their "educational" campaign would achieve full success still depended on Chinese trade practices in the coming years. ${ }^{24}$

\section{Toward the Maturation of U.S.-China Trade: 1974-1978}

The time period between 1974 and 1978 can be regarded as the second stage of direct U.S.-China trade, during which the basic trading pattern was stabilized and the Chinese traders increasingly started to adhere to the American way of doing business. This stage was crucial also because it helped to prepare for the new era of China's modernization. After the "reform and opening up" policy was officially announced in December 1978, Sino-American trade started to really "take off" as a result of the so-called "Foreign Great Leap Forward" under which China rushed to import, sometime blindly, foreign technologies and consumer goods. The new age of U.S.-China trade after 1978, however, is beyond the scope of this chapter. On the other hand, U.S.-China trade declined between 1975 and 1976, but that was caused by China's domestic turmoil. Once the "moderate" Chinese leaders consolidated their power, U.S. -China trade recovered quickly. ${ }^{25}$

For American traders, the potential of the Chinese market could not be realized unless China would reevaluate its economic policies and abandon the Maoist model of modernization emphasizing self-reliance. Transformed into specific trade practices, this required China to abandon its insistence on balanced trade and start to purchase consumer goods, not merely capital goods, from the United States. It also required China to adhere to the American standard of doing business, including accepting credits and loans, following American legal procedures, and launching aggressive marketing campaigns. In fact, since the establishment of the National Council for U.S.-China Trade, American traders had been eager to look for signs of changes in China's trade practices. In November 1973, for example, the National Council sent a delegation to China and had substantial talks with the Chinese. The talks focused on three major topics: trademark, standard contract language, and arbitration over trade disputes. The agenda was set up by the Americans and the Chinese were willing to tag along. The Chinese appeared to be practical and did not raise any political or ideological issues. Both sides agreed that they would need to establish standard trade practices and legal procedures. The Chinese, however, seemed willing to modify their practice toward American standards, and they frequently asked the Americans to provide them with legal documents to be used as "models." The National Council reported that this trip was able to "establish a basic framework for future bilateral trade" and "it was very important for American business that China would respect industrial property rights."26

There were other signs of Chinese flexibility. For example, a China trade promoter observed in early 1974 that 'the importance of foreign trade in the economic life of China received a significant boost... as a result of a decision by the Chinese government to accept larger and longer foreign credits than hitherto." Although trade was still deemed as less important than production and "tainted with capitalism," the promoter believed that "the strength of commercial instincts in China" would push China to rethink its economic system sooner or later. (Donnithome, 1974) In the 1974 Spring Canton Fair, "negotiations conducted by the Chinese were free of political overtones which characterized Fairs during the Cultural Revolution." Moreover, "American importers were surprised to see, among other things, ladies shoes in fashionable platform styles, a growing selection of brass, woodwind and string instruments, hockey sticks with curved-wood blades, large varieties of hand tools and transistor radio." (CBR, 1974d)

In fact, the Chinese internal debates which urged measures for "liberating" China's rigid trade policy started in late 1972. In October 1972, Chinese Vice Premier Li Xiannian started to emphasize the thesis that in foreign trade "price should be decided by the market." This was a "radical" thesis given that in the past price was decided and fixed by central economic planning agencies. Li pointed out that "we must respect the rules of supply and demand, and the price of goods should follow the ups and downs in the market." Li further argued that there was no need to worry about the impact of imported goods on the domestic market, and urged Chinese delegates to be flexible in trade negotiations.(CCFT, 2006a, pp. 141-142.) In March 1973, Deng Xiaoping was restored to office. Chen Yun, a top economic official, also regained power and immediately started to take over the Canton Fair. Both continued to emphasize that "price should be determined by

\footnotetext{
24“Importer's Note,” 10 November 1974, NCUSCR, Box 73, GFPL.

${ }^{25}$ "Moderates" refer to those Chinese officials who wanted to decouple ideology from economic development and who supported a less confrontational foreign policy. On the other hand, "radicals" such as the so-called "Gang of Four," wanted to continue the leftist policy of the Culture Revolution.

26،"Report of the Visit by the Delegation From the National Council to the PRC," 4-16 November 1973, NCUSCR, Box 36, GFPL.
} 
the market" and argued that "a certain degree of flexibility in deciding price according to the market is not contradictory to Marxism." As a result, during the 1973 Canton Fairs, almost 90 percent of the commodities did not have a fixed price. The report after the fairs pointed out that "we must use the rules of the capitalist market to serve our own goals." (CCFT, 2006a, pp. 152-153.)

Meanwhile, China increasingly attached more importance to trade with America. In March 1974, the Foreign Trade Ministry issued a secret study entitled "The Prospect of American Economy and U.S.-China Trade." America, the study argued, was heading toward an economic crisis. The growing stagflation, the devaluation of the dollar, the challenge from Western Europe and Japan, and the impact of the Vietnam War contributed to the decline of America's economic power. Based on this analysis, the study proposed new measures regarding trade with America. First, since America regarded China as a vast market, China should take full advantage by maximizing its economic bargaining power. Second, since Chinese goods such as tea and silk traditionally were welcomed in the American market, China should recover these markets lost during the Cold War. Third, in fifteen categories of consumer goods, such as textile, the United States relied heavily on imports. China could also produce these goods and China should try to get a share in these markets. Fourth, some Chinese goods, such as bicycles and decorations, were already welcomed by American customers. In the future China should try to enlarge these markets. Fifth, China should improve packaging techniques, send trade delegations, and use more advertisements to open the American market. China should also try to find a way to bypass high US tariffs and try to increase the value of U.S.-China trade three- or fourfold in two years. ${ }^{27}$

Those cool-headed calculations revealed that the Chinese went to great lengths to let economic, not political, rules decide China's trade policy. At the same time, the impact of the "radical" leaders on China's foreign trade was limited. In fact, it seemed that their policy was resisted at the grassroots level. One Chinese participant of the 1974 fairs, for example, later hinted that on-site Chinese traders managed to ignore the demands of the "radicals." "Every foreign trade worker knew that the "Leftist" slogans would not generate foreign currency," he recalled. "The sober fact was that we badly needed advanced technologies, equipment, and raw materials [from abroad]." (CCFT, 2006b, pp. 194-195.) Indeed, right in the middle of the heated "Second Cultural Revolution," Zhou Enlai ordered to construct new infrastructures to support the Canton Fair. By the end of 1974, Guangzhou had two new highways, one telecommunication center, and several new hotels. (CCFT, 2006a, pp.151-157.)

In fact, it seemed that U.S.-China trade relations developed faster than bilateral relations in other areas during the mid-1970s. The "moderates" in the Chinese leadership were determined to protect trade with America despite the attack from the "radicals." When the "Second Cultural Revolution" faded in 1975, the Chinese again started to actively promote trade with America. Deng Xiaoping, for example, tried to dismiss the political implications attached to foreign trade. "We should introduce new technology and equipment from other countries and expand imports and exports," Deng argued in 1975. "Foreign countries all attach great significance to the introduction of new technology and equipment from abroad. Take their products apart, and you'll find that many parts or components are also made abroad." The message was clear. If other countries did not fear foreign things, then why should China? (Deng, 1984, p. 44.)

American traders were thus convinced that China would continue to develop trade relations and shift toward the American way of doing business. In November 1974, for example, Huang Zhen, head of the PRC Liaisons office, made his first extensive tour of the United States. The tour was sponsored by the National Council, during which Huang, together with several Chinese commercial officials, visited Chicago, Detroit, Pittsburgh, Niagara Falls, and New York. The Chinese team also visited some US firms such as International Harvester, the First National Bank of Chicago, Ford, General Motors, and Westinghouse. "Huang repeatedly stressed to American business leaders a number of PRC commercial prospects and priorities, most notably the likelihood of increased oil exports," the National Council reported. The Chinese "endeavored to learn as much as possible about the American economy, polity and society by questioning individuals in plants, restaurants, gas stations and hotels." To Council leaders, Huang's tour signaled a more open mindset on the Chinese part toward America. ${ }^{28}$ The decline in the total value of U.S.-China trade in 1975 was not interpreted by the Council as a result of Chinese domestic politics. Rather, the major reason for that decline, according to the Council, was the global economic recession of the mid-1970s. In addition, the Council observed that the "fall 1974 Canton Fair saw a record number of Americans" and American now became the second largest group of foreign traders in China. "Des pite [the] projected decline [of trade in 1975]...there will be an overall increase in the proportion of US exports of machinery, technology, and plant sold to China," the Council concluded. ${ }^{29}$

The bankers from Manufacturers Hanover Trust Co. (MHT) were equally optimistic. In their contact with the Chinese,

\footnotetext{
27،The Prospect of American Economy and U.S.-China Trade," 5 March 1974, 324-2-129, GDA.

${ }^{28}$ “Report on Tour of Huang Chen and Party," November 1974, NCUSCR, Box 1, GFPL.

29،Prospects for US-China Trade 1975," 4 December 1974, Ibid.
} 
they perceived a reluctant yet gradual shift away from the self-reliance principle on the Chinese side. In November 1973, Gabriel Hauge, chairman of MHT, was eager to discuss problems with Qiao Peixin, acting chairman and general manager of the Bank of China (BOC), including fluctuations in value between the U.S. dollar and the Chinese RMB, the absence of facilities for buying RMB forward, and the lack of corresponding relationships between BOC and banks in the US. But the steps he proposed, which would start to connect the Chinese financial market with America's, were obviously too bold for the Chinese to swallow at the time. Qiao dismissed his requests with politeness, saying that China would only pay cash in trade and would not rely on foreign loans or credits. But Qiao pointed out that "China's foreign trade is developing step by step," indicating a certain interest in Hauge's proposal for future developments. ${ }^{30}$

Two years later, in November 1975, Mark E. Buchman, senior vice president of MHT, found the Chinese more open toward his proposals. Buchman found the Chinese eager to seek financial and economic information on America from him. The Chinese also asked his help straightforwardly, especially in providing credit evaluations on some U.S. firms. Buchman was thrilled: "All in all, I don't think we can expect any more for the moment. They are fully aware of who we are and are cognizant of our sensitivities...I tried to be very 'Chinese'... and emphasized we were going to be around forever and took a long view of our relationship, rather than being in for the quick buck with them." In fact, he strongly supported a long-term relationship: "What can we expect to do with them in the future?...There is substantial Sino-US trade and with the settlement of the big questions, which will come, I think the trade will grow....We should try to position ourselves for the future....I think Tai wan will eventually be neutralized into China and they hold the sword over H.K at all times. Future visits, if we can make them, are warranted." 31

Indeed, from 1975 on, things became better and better for American traders. The Chinese became even more "businesslike." "Limited quantities of industrial consumer goods continue to enter the PRC," the US China Business Review observed. "In the first place, changes in the market for these commodities constitute yet another index for measuring Chinese flexibility in interpreting the principle of self-reliance." After examining China's imports, the journal further concluded that "China is diversifying and increasing her limited imports of consumer goods...Much evidence can be marshalled [sic] to support the contention that policymakers in the PRC have adopted a relatively lenient attitude towards consumption of foreign goods among certain sections of the population." (Kamm, 1975) An American trader who attended the 1975 Spring Canton Fair reported back an e ven more relaxed political atmosphere in Guangzhou. In addition, the American traders observed that much fewer chief American business executives showed up in Guangzhou. Instead, businesses were carried out by their subordinates who really knew the day-to-day operation. This showed that now there was "more routine business" between the two countries.(CBR, 1975a)

The year 1975 saw many "firsts" in U.S.-China trade that clearly indicated the Chinese move toward adopting the American way of doing business. In October, "Good Health," a Chinese acupuncture kit, became the first "Chinese trademark authorized by the PRC for registration by an American corporation." (Sobin, 1975) The fall 1975 Canton Fair became the first fair in which American traders no longer needed to attend by invitation only. The Chinese trade representatives at the fair also "indicated a new willingness to give exclusives to US importers."(CBR, 1975b) In November, the first insurance agreement was reached between American International Group (AIG) and the People's Insurance Company of China. This agreement "will serve to facilitate Sino-US trade in a number of ways," the US China Business Review celebrated. "Comprising a reinsurance treaty, a claims settlement arrangement, and informal reciprocal technical advisory facilities, the agreement is of as much interest to US exporters to the PRC as to importers of Chinese products. It marks another milestone in the step-by-step development of US trade ties with China." (CBR, 1976a)

The Chinese stepped up their marketing effort in the United States during 1976. "American consumers and the public seem very ready to accept products from China [due to increased Chinese advertisements]," an American trader reported. A representative of JC Penny was pleased: "As the Chinese begin to understand our needs and begin to conform to and meet those needs, marketing their products will be simply a case of presenting a high-quality, low-priced product." (Miller \& Katz, 1976) By the end of 1976, the American business community mused that "it appeared as if some time last year China's FTCs decided that 1976 was going to be the year to gear up the promotion of Chinese goods in the US. America's bicentennial year has seen a splash of well-coordinated promotions of Chinese products, focusing on traditional items such as silk, carpets, and basketware. Perhaps in anticipation of this, China's FTCs have registered, via their Hong Kong agents, about a dozen trademarks in the US, a sign of a serious marketing campaign." (CBR, 1976b)

For American traders, China's new trade strategies proved that the Chinese were abandoning the Maoist model of modernization and shifting toward the American way of doing business. After the death of Mao and the downfall of the

\footnotetext{
${ }^{30}$ Gabriel Hauge, "Memo of Conversation," November 1973, National Archive on Sino-American Relations (NASAR), Box 7, Bentley Historical Library (BHL), University of Michigan, Ann Arbor, MI.

${ }^{31}$ Mark E. Buchman, “Memo of Conversation,” November 1975, Ibid.
} 
"Gang of Four" in late 1976, American traders were further convinced that the changes in China's foreign trade policy would be permanent. The Americans who went to the spring 1977 Canton Fair reported that "the general impression of most visitors was that China is returning to a state of order and preparing for a period of substantial economic development." During this Fair, China announced a new age of economic relations with the West. "The directive of Chairman Mao, first published in 1956, advocating that China must "learn from the West in technology" was one of the main themes at the fair," it was reported. Meanwhile, "the Chinese recognize that they must improve the quality, design and packaging of the wide range of consumer products now being manufactured in order to successfully market them in the West" ${ }^{32}$

Christopher Phillips later recalled that "the really dramatic change in China's policies towards foreign trade and investment came with the return to power of Deng Xiaoping in 1977." Phillips met Deng on several occasions and he was greatly impressed by the new Chinese leader: "Twice before, Deng had been purged from power for his unorthodox views. These included such statements as "It makes no difference whether a cat is black or white as long as it catches mice" and, "seeking truth from facts and putting action before ideology." Phillips believed that the rise of Deng was the turning point in China's modernization: "Those were pretty bold statements at the time. In fact, from the standpoint of orthodox Chinese communist thinking, they were almost heretical. But 'putting action before ideology' led to dramatic changes in Chinese life and in China's relations with the rest of the world. Despite our lack of diplomatic relations with China, American companies were becoming increasingly involved in China's development." 33

Change gathered more speed during late 1977. American fairgoers to the fall 1977 Canton Fair was surprised to hear the music of Mozart and Beethoven broadcasted on the loudspeakers. Christmas decorations appeared on the Chinese export list for the first time, and American buyers were amazed when the Chinese offered to pack porcelain with Styrofoam to reduce breakage during transportation. China's FTCs, in short, had adopted a "down-to-business" attitude. (Mathews, 1977) The 1978 Canton Fairs saw even more dramatic changes. The Chinese set up a coffee shop with hamburgers in the hotels for their customers. For the first time, representatives of the Chinese producers were allowed to participate in business talks with foreign companies. More amazing to American traders, the Chinese FTCs started to compete among themselves for foreign business, offering lower price and faster delivery. The Americans soon discovered that the reason was the reintroduction of material incentives back into the Chinese foreign trade bureaucracy, which induced Chinese trade officials to work harder. ${ }^{34}$ The National Council also observed "China's increased willingness to comply with US government regulations such as FDA requirements, labels on garments, manufacture for export according to specifications and designs of buyers." The Board of Director even decided that the next task for the Council was to study the possibility of joint-venture with the Chinese. ${ }^{35}$

Meanwhile, economic relations with America figured prominently in China's new national policy of "Four Modernizations." In late 1977, China sent a large delegation to America, which included representatives from Foreign Trade Ministry, Foreign Ministry, Central Economic Planning Council, First Machinery Ministry, Petroleum Ministry, Shanghai Government, and other key economic departments. The delegation widely toured American industries and concluded that "we should learn from America [in various areas]." The delegation then made a long list of desirable imports from the United States. ${ }^{36}$ On April 21, 1978, the Foreign Trade Ministry further instructed that China should get out of the shadow of the Cultural Revolution as soon as possible and continue to expand trade with America. Noticing the rapid growth of U.S.-China trade in 1977, the ministry observed that "more and more American businessmen be came interested in our Four Modernizations." As a result, the ministry concluded, "we can develop trade with America even without the normalization of relations. ${ }^{\circ 37}$

Of course, soon China and America were going to establish formal diplomatic relations. And soon China was going to announce the new "reform and opening up" policy. Trade between America and China was going to reach a new stage of development. In many ways, direct U.S.-China trade between 1975 and 1978 helped to prepare the two countries for the coming new era. Not only did the two sides become more experienced in dealing with each other; the Chinese adoption of the American way of doing business also contributed to the change in China's own model of modernization.

\footnotetext{
32،"Spring 1977 Fair,” NCUSCR, Box 71, GFPL.

${ }^{33}$ Oral History of Christopher Phillips, FAOHC.

34،Report on Fall 1978 Canton Fair," 23 November 1978, NCUSCR, Box 76, GFPL

35“"Board Meeting," 14 June 1978, NCUSCR, Box 2, GFPL.

${ }^{36}$ “Report on Delegation to the US," 24 November 1977, 235-2-242, GDA.

37“"On US-China Trade,” 21 April 1978, 235-2-163, GDA.
} 


\section{Conclusion}

Between 1971 and 1978, direct U.S.-China trade resumed and developed rapidly despite bumps in China's domestic politics and the two countries" official relations. The discourse on China's modernization underlined the trajectory of Sino-American trade. For American traders, the perceived Chinese failure in modernization guaranteed the Chinese need for trading with America, which constituted a solid foundation upon which Americans could nurture the China market. Thus, despite the problems of the bilateral trade, many Americans decided to hang on in the China market. When China indeed became more flexible in its trade policy, Americans took it as proof that China was revaluating its model of modernization. In return, American traders were further convinced that it was worth the effort to have long-term strategies regarding the China market.

Of course, it is not necessary to portray American traders as noble crusaders who wanted to modernize China along the Western way. American traders, in fact, preferred the attitude that "business is business" and wanted very much to separate trade from ideology. Yet at the same time, many American traders were aware that their activities in China would have enormous impact on China's modernization over the long term. Moreover, successful trade with China required the Chinese to change their trade policy, which, after all, was deeply rooted in the Maoist economic model. Thus, American traders indeed served as "unofficial ambassadors" who helped to negotiate a better term for U.S.-China relations.

Finally, it is necessary to point out that American traders were not the only traders from capitalist countries that the Chinese encountered during the 1970s. In fact, the Chinese were able to play off other foreign traders against the Americans from time to time. Although China's trade with countries such as Japan, France, and West Germany was not discussed in this article, we can still argue that trade with America played the leading role in China's reevaluation of its economic model. After all, without the U.S.-China rapprochement, it would have been hard to imagine that China could do extensive business with those countries in the first place.

\section{References}

Ali, S. M. (2005). US-China Cold War Collaboration, 1971-1989. New York: Routledge.

American Management Association (AMA). (1972). Trade with China: An AMA Research Report. N.P.: American Management Association, Inc.

Boarman, P. (Eds.). (1974). Trade With China: Assessments by Leading Businessmen and Scholars. New York: Praeger Publishers.

Brozan, N. (1972, May 18). To China and Back. New York Times, p. 42.

CBR Staff Writer. (January-February, 1974b). How to Start Imports from China. US China Business Review, pp. 7-8.

CBR Staff Writer. (March-April, 1976a). First US Insurance Agreement with PRC Establishes a Good Precedent. US China Business Review, pp. 3-6.

CBR Staff Writer. (May-June, 1974c). Fashion Goods from China. pp. 20-21.

CBR Staff Writer. (May-June, 1974d). The Spring 1974 Canton Fair. US China Business Review, pp. 42-54.

CBR Staff Writer. (May-June, 1975a). Kwangchow Diary Spring 1975. US China Business Review, pp. 43-49.

CBR Staff Writer. (November-December, 1975b). Canton Fair Fall 1975. US China Business Review, pp. 54-56.

CBR Staff Writer. (November-December, 1976b). China Steps Out in the US. US China Business Review, pp. 8-15.

Center of China Foreign Trade (CCFT). (2006a). Baijie Huihuang, 1957-2006 (Memorial of 100 Sessions of Canton Fair, 1957-2006). Guangzhou: Nanfang Ribao.

Center of China Foreign Trade. (2006b). Qinli guangjiaohui (My Experience of the Canton Fair). Guangzhou: Nanfang Ribao.

Chang, G. H. (1990). Friends and Enemies: The United States, China, and the So viet Union, 1948-1972. Stanford, CA.: Stanford University Press.

Chang, G. H. (2015). Fateful Ties: A History of America's Preoccupation with China. Cambridge, MA: Harvard University Press. https://doi.org/10.4159/9780674426115

Chen, J. (2001). Mao's China and the Cold War. Chapel Hill: North Carolina University Press.

Cheung, G. C. K. (1998). Market Liberalism: American Foreign Policy toward China. New Brunswick and London: Transaction Publishers.

Cohen, W. I. (2000). America's Response to China: A History of Sino-American Relations (4th ed.). New York: Columbia University Press. 
Deng, X. P. (1984). Selected Works of Deng Xiaoping. Beijing: Foreign Language Press.

Donnithome, A. (January-February, 1974). China’s Foreign Trade System Changes Gear. US China Business Review, pp. 16-21.

Fairbank, J. K. (1983). The United States and China (4th ed.). Cambridge, MA: Harvard University Press.

Foot, R. (1995). The Practice of Power: U.S. Relations with China since 1949. Oxford: Clarendon Press.

Førland, T. E. (2009). Cold Economic Warfare: CoCom and the Forging of Strategic Export Controls, 1948-1954. Dordrecht, The Netherlands: Republic of Letters Publishing.

Garrison, J. A. (2005). Making China Policy: From Nixon to G. W. Bush. Boulder, Colo.: Lynne Rienner Publishers.

Garthoff, R. L. (1994). Détente and Confrontation: American-Soviet Relations from Nixon to Regan. Washington, D.C.: Brookings Institution.

Garver, G. W. (1982). China's Decision for Rapprochement with the United States, 1968-1971. Boulder, CO: Westview Press.

Harding, H. (1992). A Fragile Relationship: The United States and China since 1972. Washington, D.C.: The Brookings Institution.

Jackson, I. (2001). The Economic Cold War: America, Britain and East-West Trade, 1948-63. Basingstoke: Palgrave Macmillan. https://doi.org/10.1057/9780230510920

Kamm, J. (March-April, 1975). The Market in China For Foreign Consumer Goods. US China Business Review, pp. 4-15.

Kamm, J. (November-December, 1978). Canton 44. US China Business Review, pp. 21-32.

Kirby, W. C., Ross, R. S., \& Gong, L. (Eds.). (2005). Normalization of U.S.-China Relations: An International History. Cambridge, MA: Harvard University Press. https://doi.org/10.2307/j.ctt1 tg5q2k

Kochavi, N. (2002). AConflict Perpetuated: China Policy during the Kennedy Years. Westport, Conn.: Praeger.

Komine, Y. (2008). Secrecy in U.S. Foreign Policy: Nixon, Kissinger and the Rapprochement with China. Aldershot, England: Ashgate Publishing Limited.

Kwitny, J. (1971, March 11). The China Trade. Wall Street Journal, p. 1.

Lubman, S., \& Lubman, J. (January-February, 1974). An Importers Introduction to the Canton Fair. US China Business Review, pp. 33-35.

Lumbers, M. (2008). Piercing the Bamboo Curtain: Tentative Bridge-Building to China during the Johnson Years. Manchester and New York: Manchester University Press. https://doi.org/10.7228/manchester/9780719077784.001.0001

MacMillan, M. (2007). Nixon and Mao: The Week That Changed the World. New York: Random House.

Mann, J. (1999). About Face: AHistory of America's Curious Relationship with China, from Nixon to Clinton. New York: Alfred A. Knopf.

Mastanduno, M. (1992). Economic Containment: CoCom and the Politics of East-West Trade. Ithaca, NY: Cornell University Press.

Mathews, J. (1977, November 18). US Businessmen Flood Canton Fair. The Washington Post, p. F1.

Miller, K., \& Katz, J. (September-October, 1976). The Promotion of Chinese Consumer Products in the USA. US China Business Review, pp. 3-5.

Nixon, R. (1967, October). Asia after Vietnam. Foreign Affairs, pp. 111-125. https://doi.org/10.2307/20039285

Peck, J. (2006). Washington's China, The National Security World, The Cold War, and The Origins of Globalism. Amherst \& Boston: University of Massachusetts Press.

Qing, S. M. (2007). From Allies to Enemies: Visions of Modernity, Identity, and U.S.-China Diplomacy, 1945-1960. Cambridge, Mass.: Harvard University Press.

Ross, R. S. (1995). Negotiating Cooperation: The United States and China, 1969-1989. Stanford: Stanford University Press.

Ross, R. S. (Eds.). (1998). After the Cold War: Domestic Factors and U.S.-China Relations. Armonk, NY: M.E. Sharpe.

Schaller, M. (2001). The United States and China: Into the Twenty-First Century (3rd ed.). New York: Oxford University Press. 
Segal, G. (Eds.). (1982). The China Factor. London: Groom Helm.

Sobin, J. (November-December, 1975). The First Chinese Mark Registered in the US. US China Business Review, pp. 3-6.

Stahnke, A. A. (Eds.). (1972). China's Trade with the West: A Political and Economic Analysis. New York: Praeger Publishers.

Sutter, R. G. (1983). The China Quandary: Domestic Determinants of U.S. China Policy, 1972-1982. Boulder, CO: Westview Press.

Sutter, R. G. (2010). U.S.-Chinese Relations: Perilous Past, Pragmatic Present. Lanham, MD: Rowman \& Littlefield Publishers.

Tillett, L. (November-December, 1974). An American Market Designer Visits China. US China Business Review, pp. 54-57.

Tucker, N. B. (1983). Patterns in the Dust: Chinese-American Relations and the Recognition Controversy, 1949-1950. New York: Columbia University Press.

Tudda, C. (2012). ACold War Turning Point: Nixon and China, 1969-1972. Baton Rouge, LA: Louisiana State Uni versity Press.

Tyler, P. (1999). AGreat Wall: Six Presidents and China. New York: The Century foundation and Public Affairs.

US China Business Review (CBR) Staff Writer. (January-February, 1974a). Council Delegation in Peking. US China Business Review, pp. 3-5.

Wall Street Journal (WSJ) Staff Reporter. (1971, April 28). China Trade: A New US Policy. Wall Street Journal, p. 1.

Wang, C. (2013). The Unite States and China since World War II. New York: M. E. Sharpe.

Whitson, W. W. (Eds.). (1974). Doing Business with China: American Trade Opportunities in the 1970s. New York: Praeger Publishers.

WSJ Staff Reporter. (1972a, March 29). Boeing Has Been Talking With Peking on Jet Sale. Wall Street Journal, p. 15.

WSJ Staff Reporter. (1972b, July 6). Boeing Confirms US Clears Permit for Sales to Peking. Wall Street Journal, p. 6.

WSJ Staff Reporter. (1972c, September 12). Boeing Confirms Accord for Sale of 707s to Peking. Wall Street Journal, p. 8.

WSJ Staff Reporter. (1972d, November 2). US Businessmen Find Haggling With Chinese Is Exhausting Work. Wall Street Journal, p. 1.

Xia, Y. F. (2006). Negotiating With The Enemy: U.S.-China Talks During The Cold War, 1949-1972. Bloomington, IN: Indiana University Press.

Xu, G. Q. (2014). Chinese and Americans: A Shared History. Cambridge, MA: Harvard University Press. https://doi.org/10.4159/harvard.9780674736290

Zhang, S. G. (2001). Economic Cold War: America's Embargo against China and the Sino-Soviet Alliance, 1949-1963. Stanford, CA: Stanford University Press.

\section{Copyrights}

Copyright for this article is retained by the author(s), with first publication rights granted to the journal.

This is an open-access article distributed under the terms and conditions of the Creative Commons Attribution license which permits unrestricted use, distribution, and reproduction in any medium, provided the original work is properly cited. 